\title{
Is ecotourism a viable option to generate wealth in brittle environments? A reflection on the case of the Sierra Gorda Biosphere Reserve, México
}

\author{
P. J. Gutiérrez-Yurrita, L. A. García-Serrano \& M. Rebollar Plata \\ Centro Interdisciplinario de Investigaciones y Estudios Sobre \\ Medioambiente y Desarrollo - Instituto Politécnico Nacional, México
}

\begin{abstract}
Ecotourism has been considered as the most important activity for generating wealth and restoring social ties of marginalized groups and less developed economies of fragile environments in Mexico. Indigenous communities live in well-preserved forest sites, but with small population size and proximity to areas completely degraded, they are the most vulnerable to collapse. The Biosphere Reserve Sierra Gorda is a protected natural area that has all the characteristics to develop ecotourism activities: rural tourism, adventure tourism, health tourism, recreational tourism and educational tourism of nature. But likewise, it is an area that faces severe environmental problems by excessive logging, fires, clearing for cattle pastures and agriculture land. But mostly habitat destruction for housing construction. Near the small centres of the population there are major geological faults and deep canyons carved by the action of river water. Water and wind are the most important natural phenomena that have shaped the mountain landscape and each year make it deeper and wilder. Pre-Hispanic communities inhabit those inhospitable to modern man with a type of European culture: Pahmes, HñäHñü, Chichimecas and Nahuas. Many productive projects have been conceived in this area, with more failures than successes and always, leave the regional economy more and more battered. The destruction of the environment has become a usual habit. Ecotourism has only served so people from other places have access to wild regions and transform it into something like a recreational park. Ecotourism is quite irresponsible. Ecotourists often lack culture, respect for social groups that inhabit the places visited, and leave the
\end{abstract}


economic benefits to large travel agencies instead of leaving it to local communities. In this paper we address these issues and try to answer the key question: "Is ecotourism a viable production option in fragile environments? The reflection is conducted through an analysis of the holistic ecology to managing our landscape heritage in a sustainable way.

Keywords: holistic ecology, fragile environments, responsible tourism, naturally protected areas, ecological law, conservation biology.

\section{Introduction}

The idea that ecotourism differs from other types of tourism as a kind of activity environmentally and socially responsible is not new. It is a tourism that promotes cultural exchange between locals and visitors; favours the environmental consciousness among tourists and the transmission of native knowledge to the stranger. In the economic sphere, ecotourism has been conceived as a source of wealth in local communities [1]. A safe and effective way to overcome poverty and to augment locals' quality of life without great deterioration of the natural landscape is the perspective of the responsible tourism (ecological, rural, cultural, scientific or health tourism, for instance).

Mexico is a country with a high index of social marginalization, where extreme poverty and educational backwardness are the normality. However, the country has a huge rich natural Capital and wilderness [2]. It is one of the five countries with biological Megadiversity [3]. By these reasons tourist activities are one of the most important income sources to federal government and people.

Mexico is the second country in the world with ethnic and linguistic diversity. There are about 62 languages. More than 7,000.000 people used to speak in their own language. The most abundant languages are Nahuatl (more than 1,500.000 speakers), Maya $(790,000)$ and Mixteca $(500,000)$ [4]. However, it is important to note that the state of the republic with more indigenous people is the poorest in the nation: Oaxaca. But it is also one of the richest states in ecosystems not disturbed by human activities [5]. And therefore, with greater potential for ecotourism.

Another region similar to Oaxaca [in social, economic and ecological importance] is the Huasteca. Five states of the Mexican republic converge on the Huasteca. One of these states is Querétaro. Practically the entire queretanean Huateca is a protected natural area, named "Sierra Gorda Biosphere Reserve" (SGBR). Mountains, hills, valleys, wetlands, rivers and clear streams are some of the landscapes that can be enjoyed in Sierra Gorda. Food pahme, hñähñü and nahuatl can be enjoyed. A variety of clay, rattan, wood, precious stones and handicrafts are available at very low prices. However, on the other side of the coin there is the extreme poverty of indigenous communities; few opportunities of economic development; and the increasing loss of indigenous identity, among others [6].

Ecotourism is seen as an activity that can promote local development in all areas (economic and social), and also is wary of the environment. The capital generated by this activity would be used to improve the living standards of local 
communities: better housing, more schools, neighborhoods with all amenities and services. However, the reality is very different. The wealth generated stays in the travel agencies that organize tours. The degradation of ecosystems with high-impact activities, such as All-Terrain Vehicles (ATVs), motor boats on small lakes, rafting, are the ordinary. The negative results to promote ecological tourism in Sierra Gorda make us rethink the meaning of ecotourism; especially when fragile environments are at risk and when many biological species are endangered [7].

Because it is becoming necessary for researchers and students of ecology sciences to know something of social and economic sciences. And for politicians, individuals, investigators and students of social and economic sciences to know something of ecology and conservation biology, this text is designed to bridge these fields by acquainting all the individuals with the major environmental hazards, both man made and natural, and with the risk to human health and wealth that they pose. Ecotourism is a human activity that serves as a good example of how public policy can develop a holistic approach to managing our natural resources.

\section{Description of the area of study}

Querétaro is located in the Central part of the Mexican Republic. SGBR is located at the north-eastern part of the State of Querétaro into the Sierra Madre Oriental; the SGBR covers 383.567 has, contains 11 core protected areas that cover 24.803has; the buffer zone covers 358.764has. The SGBS has approximately 100,000 citizens living in 638 localities [8]. In the Sierra Gorda there are high rates of migration recorded for the reason that the field is considered increasingly less profitable. The rural population is dispersed in hundreds (638) of small communities scattered across the SGBR territory.

SGBR is in the junction of the Neartic and Neotropical Biogeographical regions, including three physiographical provinces: Neovolcanic axis, the Central Plateau (Bajío) and the Sierra Madre Oriental. A great hydrological basin cross the SGBR: the basin of the Moctezuma-Pánuco river system (Fig. 1). Because of the high variation in altitude $(0$ to $+2500 \mathrm{~m}$ above sea level $)$ and the three climates identified (warm, dry, temperate), the following types of vegetation are found in this area: desert scrub, thorn woodlands, pine forest, oak forest, temperate hardwood forest, low tropical deciduous forest and agricultural lands. Many aquatic fauna and macrophytes naturally inhabit shallow, clear, running waters, riffles areas of the streams with no pollution, or not greatly altered by man. Riparian vegetation, rocks, pebbles and cobbles are of considerable importance for invertebrate survival, because during the night, they rest and look for food within macrophyte mass and roots, and inside the great amount of debris deposited in river or stream pools. During the day, aquatic insects hide under the rocks [9]. 


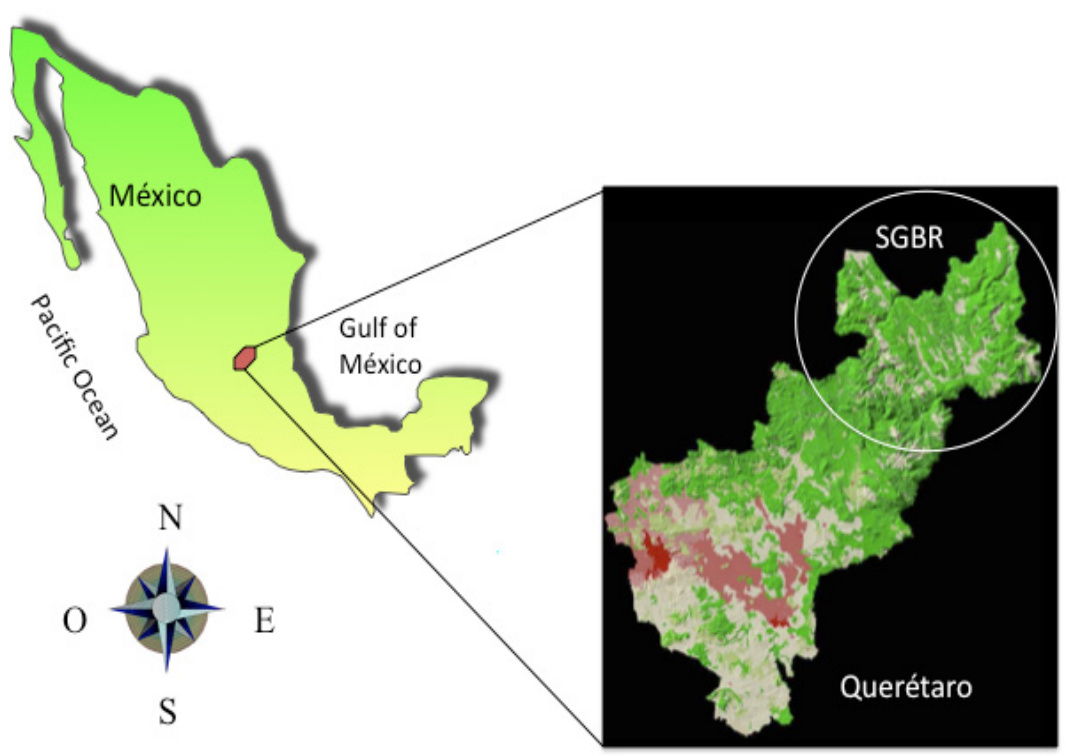

Figure 1: Location of Sierra Gorda Biosphere Reserve at the northern part of the State of Querétaro in México.

Because aquatic systems (rivers and springs) are the most visited places for touristic activities, we are going to describe with more precision than terrestrial habitats. And also because terrestrial habitats, mammals and birds are much more studied [10]. Physicochemicals of many water bodies range from 20 to $28^{\circ} \mathrm{C}$; 8 to $12 \mathrm{mg} \mathrm{l}^{-1}$ of oxygen; $\mathrm{pH}$ from 7 to 8 , total hardness ranges from 90 $350{\mathrm{mg} \mathrm{CaCO} 3 \mathrm{l}^{-1}}^{2}$ 11]. Vegetation that surrounds the rivers are mainly gallery woods (Taxodium mucronatum Tenn. and Salix Kunth), pines and oaks in the springs, and banana's, mango's and peaches' trees in plantations (canyon's low lands); though hydrophytes are scarce in several places, Aster subulatus Michx., Cyperus flavescens L., Cyperus niger Ruiz and Pavón, Typha latifolia L., are the most representative of the highland streams. The exotic macrophytes such Eichornia crassipes (Mart.) Solms., Egeria densa Planch and Lemna gibba L. are the most abundant in slow-flow rivers; Lemna aequinoctialis Welw., Polygonum lapathifolium L., Bacopa procumbens (Mill.) Greenm., Bacopa monnieri (L.) Wettst., Hydrocotyle verticulata L., Eleocharis macrostachya Britton, Najas guadalupensis (Spreng.) Magnus and Potamogeton diversifolius Raf. are other macrophytes present in many aquatic systems of the SGBR [12]. The major animal community is comprised of benthonic macroinvertebrates (Palemonidae: Macrobrachium carcinus L, Macrobrachium olfersi (Wiegmann)), Dytiscidae (Laccophilus Leach.), Hydrophilidae (Tropistermus), Tricoptera, Heteroptera, Notonecta, Diptera (Culicidae and Chironomidae) [13], and larvae of Odonata (Hetaerina Hagen and Seliys, Anax Leach, Aeshna Fabricius, Libellula L.) [14]; zooplankton community is assembled by Daphnia, Copepoda and Amphipoda; the most representative fish species are Poecilia 
mexicana Steindachner, Heterandria bimaculata (Heckel), Goodea atripinis [Hubbs and Turner] and Astyanax mexicanus (Filippi) [15]. The ecological importance of this region can be seen in the large number of new species discovered in science of aquatic macroinvertebrates in recent years [5].

\section{Results and discussion}

One of the thrusts of modern eco-tourism is to identify areas of biological importance based on their great biodiversity, species richness, endemism, and biological distinctiveness. Whereas for the conservation biology it is also very important to identify species assemblages that inhabit these special areas or the highly specialised, unique or restricted habitats, since they are considered to be especially vulnerable to extinction [16]. The watersheds of SGBR have most, if not all of these traits, since they are brittle environments because they are located in the junction of Biogeographic regions (Neotropic and Neartic), three freshwater of North America ecoregions 1) Río Verde Headwaters; 2) Tamaulipas-Veracruz; and 3) Lerma [17], and in the transition area of three physiographic provinces: 1) Neovolcanic sierras and plains, 2) Mexican high plateau and 3) Eastern Sierra Madre, and, they are exposed to great urban, agricultural and touristic pressure. Under this perspective, the geographic position of SGRB raises interesting biogeographical questions about the origins of its biodiversity, much of which is endemic and inhabits brittle environments, and about how to develop indigenous communities without damaging these fragile ecosystems or without loss of biodiversity.

Two areas from the region are considered Priority Class I for North America freshwater ecosystems conservation because they remain relatively undegraded and have high biological distinctiveness levels. And they are exposed to intensive tourism especially at Easter, Christmas holidays and summer time. These two hot spots are the section of the Lerma River located in the state of Querétaro, and the Moctezuma basin. In the ecoregion Lerma, although there is one small-protected area, the most important threats for biological diversity are the alteration of the habitats bay agriculture activities and by extreme tourism including rafting, jeep rallys, routes for ATVs and paragliding. To a lesser extent, deterioration of these areas is due to pollution, and heavy surrounding land uses (especially industry). Exotic fauna, mainly fishes (for instance: carps Cyprinus carpio (L), black bass Micropterus salmoides (L) and Carassius auratus (L)), are of considerable impact to the local biota. The Moctezuma basin hot spot is distinguished by a high degree of endemism in fish and crayfish [2, $12,17]$.

In addition, although SGBR is a naturally protected area inside the aforementioned Priority class I region, biological species and its eco-diversity are threatened by overexploitation of water, especially underground water, salinisation from agriculture and industry, human population pressure, and introduction and translocation of exotic species [17]. These exotic species are fishes such as tilapias Oreochromis mossambicus Peters, Oreochromis aureus Steindachner and Oreochromis niloticus L, black bass M. salmoides, sun fish 
Lepomis macrochirus Rafinesque, and one native cichlid Cichlasoma cyanoguttatum (Baird and Girard) [15]. It is important to note that locals report that they have found exotic crayfish in their waters (Concá river), though we have never caught any. These exotics may be the consequence of efforts to culture Cherax destructor Clark and/or Cherax quadricarinatus Clark since 1995 in this area.

Whereas, some biological species have not been severely affected by human activities and are currently invading degraded environments of the Moctezuma river basin, some habitats and other species are very sensitive to human perturbations. Major threats to brittle environments inside the SGBR are habitat loss and fragmentation of habitat, since many of the species that belong to these ecosystems have restricted distributional ranges. Moreover, many endangered species exist as relict populations, especially in "the Bucareli arroyo". Gilpin and Soulé [18] and Taylor [19] stated that species with narrow distributional ranges should not be denied conservation attention, because they are extremely vulnerable to extirpation. Thus, some crustacean species in SGBR, must be listed in the red book of threatened and endangered species from México, and they must be considered a priority for their preservation.

Because modern practices in Conservation Biology are trying to protect habitats and/or ecosystems rather than to preserve species alone, it is very important to improve the efforts of conserving the ecological processes of the ecosystems from the Sierra Gorda Biosphere Reserve, where as with macrocrustaceans (Procambarus yagoii, Macrobrachium carcinus and Macrobrachium olfersi), these areas also have many endemic fish such as Notropis sellaei (Günter), Ictalurus australis (Meek), Ictalurus mexicanus (Meek), Gobiomorus dormitor Lacépède, and Pilodictis olivaris Rafinesque [15]; rare species of dragonflies from the genus Myathiria Kyrbi, Dythemis Hagen and Progomphus Selys [14]; among other groups of hydrophytes or plants associated to water (Thypha latifolia L., T. Mucronatum, Platanus mexicana Moric., Ludwigia peploides (Kunth) Raven, Hydrocotytle ranunculoides L., Mimulus glabratus Kunth, Zannichellia palustris L., Callitriche deflexa Braun ex Hegelm), for instance [20]. More important, in a few streams that flow into the Moctezuma river, near Tangojó (Landa de Matamoros municipality).

Because the major threats for SGBR are habitat loss, habitat deterioration, pollution and introduction of exotics due to touristic activities rather than industrial activities, the management action plans could focus on the necessary actions for a reasonable (sustainable) management of the ecotourism activities in many forms, especially in adventure tourism and extreme tourism. At present, any wise use of the ecosystems has considerable potential for improving the survival of the endangered species as well as the preservation of the entire ecosystem (maintaining its resilience).

Finally, we mention the local communities where tourist activities do not benefit from such activities. Companies promoting adventure tourism, travel agencies and foreign guides to the community, are the direct beneficiaries of the economic flow that leaves tourism. These groups and guides even get to tell tourists not to consume foods that they do not provide them with or they will not 
be responsible for their health. When they take the tourists to see crafts, they just do it if they have an agreement with any person, and they earn a percentage of sales. In summary, these promoters are predators and corrupt and they do not want to show tourists local traditions, culture,or teach them how to behave in the wild.

\section{How to move forward}

First, change the paradigm of how to see ecotourism: The holistic approach that arises under the model of the Third Culture means functionally combine technical knowledge with humanistic and biological evolution. It involves planning a landscape management as if it were a world heritage site, suggestshthat biological conservation pass through the sieve of the so called city regions, in the sense that tourists learn to live with the local communities they visit and in harmony with enjoying the wild.

Second, with respect to the conservation biology and fragile environments, further studies concerning the ecology of rare species such as cave and underground water species should also be a research priority to determine levels of environmental flexibility of these biological diversities. In addition, studies to understand how to preserve, not only the species, but also the ecological processes of these singular ecosystems are needed.

Third, on social issues, the promoters of ecotourism activities should enable tourists on environmental education topics to generate in them sensitivity and environmental awareness. In this way, tourists would change their attitude towards nature and would have more respect for the customs of the people living in the areas visited.

There is an urban legend commonly held in our society that any activity with little infrastructure and developed individually in natural areas is good, healthy and does not harm the environment [21]. This is one of the central ideas that supported activities in protected natural areas under the name of ecotourism then came many variants like adventure tourism, extreme tourism, rural tourism and most recently responsible tourism. We need to recognize that any human activity changes our environment. Environmental change is driven by the things we eat, make, build and buy and by the decisions we make as citizens [22]. During the last century we have acquired the power to change the overall functioning of the planet. The human population is projected to increase to about 9 billion in the future. The biodiversity of the planet is under heavy stress, mass extinction of biological species and eco-diversity loss is under way, and scientists predict that a quarter of all species could be pushed to extinction by 2050 as a consequence of both, natural perturbations and human activities [23].

Even though since 1972 the united nations marked the beginning of an international environmental policy, efforts to combine and carry out an environmental agenda have been less fruitful [24]. Many social and economic aspects are the major cause, if we walk slowly down the path of sustainability, however, with recent advances in the integration of science with the humanities, we can generate a holistic strategy to conserve our natural resources, overcome 
poverty and inherit a better world for our descendants. Mexico has to pay more attention to education, both rural and urban settings. Generating environmental awareness in each citizen should be a priority and to subsequently develop a policy of state that can be truly public. A state policy, not only an environmental policy. In the state policy should be included in a transversal way, how to address the social, economic and environmental challenges we need to make Mexico a sustainable country. So yes, ecotourism activities in protected natural areas will be a good option to generate wealth and protect, at the same time the environment [25].

\section{Conclusions}

The most serious problem facing conservation biology in Mexico is that the poorest rural populations living in the richest places in natural resources and ecologically be preserved. So to develop the economy of these communities, we have to damage ecosystems and deplete resources, unless we find economic activities compatible with the wild and with the culture of the indigenous people. At first it was thought that ecotourism could be this great option. However, a bad design of these activities has led to results contrary to those expected in Mexico. A clear example is that the economic benefits do not stay in indigenous communities, but in large tourism enterprises.

However, many ecotourists believe that the solution to the dual problems of low production and low prices in rural areas in México could be overcome by introducing alien species, appetizing for them. These tourists recognise the urgent need to develop human resources, institutional capabilities, as well as an appropriate legal framework and public policies to enable México to take an active part in the new economy associated with the use of biological diversity, genetic resources and biotechnology; emphasise the importance of traditional knowledge of indigenous and local communities for the preservation of biological diversity, the development of that knowledge and the sustainable use of its components; has decided to promote in situ and ex situ conservation of biodiversity in the region of origin and develop projects to make inventories of Mexican resources and invest in the development and use of endogenous technologies that support the conservation of genetic materials and economic activities sustainable at local level.

At present, public administration has not: established regulatory frameworks to ecotouristic activities, or frames to create incentives for the conservation and sustainable use of biological resources, taking into account existing sub regional efforts and initiatives; economically supported the programs developed by CONACYT to encourage and extend greater scientific, technical and biotechnological cooperation including exchanging experts, training human resources and developing research-oriented institutional capabilities in order to add value to the goods and services generated through biodiversity and ecosystems, while ensuring the development of biotechnology; or jointly [Federal administration in association with governments of the Mexican States and other countries] combat the illegal acquisition of genetic resources, by 
exchanging information about negative practices by private [tourists] or academic institutions, and develop mechanisms to control the final use of the genetic resources.

On the contrary, the Mexican government is promoting activities that generate wealth in the short term with little public and private investment; productive activities such as culture of exotic species without environmental impact studies prior to the introduction, or with a very light studies concerning import risk analysis (the process which provides importing countries with an objective and defensible method of assessing the disease risks associated with the importation of animals according to OIE 2001) (NOM-010-PESC-93), just because these species are known by tourists and they can consume them more easy than native species, among other causes. For this reason some research Centres are dedicated to adapt the original culture methods to Mexican conditions in terms of habitat requirements, availability and quality of food, and social and economic Mexican reality.

It is relevant to note that researchers must be warned that exotic species are very competitive with natives ones, and that they must conduct investigations concerning how to prevent natural damages if some of the alien individuals escape, how to control alien populations in the wild, and how to ameliorate the negative impact on ecosystems caused by the feeding activity of these species.

Environmental awareness is an instrument that if part of a holistic public policy, promotes a shift in our habits, attitudes and vision of nature. Thus, if ecotourism develops more as a socially and environmentally responsible tourism, it could be the alternative that Mexico needs to overcome the dual challenge of preserving our landscape heritage and overcoming rural poverty rates.

An example of how ecotourism may be developed can be seen in activities that promote Sierra Gorda Ecotours and the direction of the Biosphere Reserve Sierra Gorda, but are rare and facing in addition to illegal activities undertaken by other sectors that make at risk the lives of tourist guides and even the tourists themselves.

\section{References}

[1] Torres, A., Flores, J. and Cruz, K. Turismo rural: emprendimiento de base ecológica. Avances en el estudio de patrimonio paisajístico de México, ed. Gutiérrez-Yurrita, P. J. and Muñoz Sevilla, N.P. IPN. México (in press). 2012.

[2] http://www.conabio.gob.mx/informacion/gis/ web-page visited on March 2012.

[3] Llorente-Bousquets, J. and Ocegueda, S. Estado del conocimiento de la biota, en Capital natural de México, vol. I: Conocimiento actual de la biodiversidad. Conabio, México, pp.283-322. 2008.

[4] http://www.inegi.org.mx/sistemas/mexicocifras/ web-page visited on march 2012.

[5] Gutiérrez-Yurrita, P. J., Alonso, P., Hurtado, S., Morales, J., Bautista, E., Pedraza, C. and López-Romero, A. Estudios ecosistémicos en la Reserva de 
la Biosfera Sierra Gorda, Querétaro. Memorias del Primer encuentro de Investigación sobre la Sierra Gorda. UNDP-CONANP. pp.279-298. 2005.

[6] Gutiérrez-Yurrita, P.J. How to restore riverbanks in natural ecosystems with many people using ecological services at the same time? Chemical Engineering and Applications, 23, pp.15-20. 2011.

[7] http://sierragorda.conanp.gob.mx/ web-page visited on march 2012.

[8] GutiérrezYurrita, P. J. and Padilla, U. Análisis sintético de la fauna queretana y estrategias para su gestión y preservación (9 Anexos aparte de 160pp.). SEDESU. México. 2004.

[9] Arellano, A., Padilla, U., Pedraza, R. and Gutiérrez-Yurrita, P. J. Aves. Análisis sintético de la fauna queretana y estrategias para su gestión y preservación., eds. GutiérrezYurrita, P. J. and U. Padilla, SEDESU. México. pp.45-53. 2004.

[10] Pedraza-Lara, C., López-Romero A. and Gutiérrez-Yurrita, P. J. Preliminary Studies Concerning Phenotype And Molecular Differences Among Freshwater Crayfish From The Genus Procambarus In Sierra Gorda Biosphere Reserve, México. Freshwater Crayfish, 14, pp.232-240. 2004.

[11] Gutiérrez-Yurrita, P. J., Morales, J., Oviedo, A. and Ramírez-Pérez, C. Distribution, spread, habitat characterisation and conservation of the crayfish species (Cambaridae) in Querétaro (Central México). Freshwater Crayfish, 13, pp.288-297. 2002.

[12] Gutiérrez-Yurrita, P. J. The use of the crayfish fauna in México: Past, Present... and future? Freshwater Crayfish, 14, pp.45-51. 2004.

[13] Hurtado, S., García-Trejo, F. and Gutiérrez-Yurrita, P. J. Importancia Ecológica De Los Macroinvertebrados Bentónicos de la Subcuenca del Río San Juan, Querétaro, México. Folia Entomológica Mexicana, 44(3), pp.271-286. 2005.

[14] Alonso-Eguía Lis, P., González-Soriano, E. and Gutiérrez-Yurrita, P. J Listado y distribución de los odonatos de la Cuenca del Río Moctezuma, Centro-Occidente de México (Insecta: Odonata). Folia Entomológica Mexicana, 41(3), pp.347-357. 2002.

[15] Gutiérrez-Yurrita, P. J. and Morales, J. Síntesis y perspectivas del estatus ecológico de los peces del estado de Querétaro (Centro de México). Homenaje al Doctor Andrés Reséndez Molia. Un ictiólogo mexicano, eds. Dirección de Publicaciones Universidad Autónoma de Nuevo León, Monterrey, México. pp.217-234. 2004.

[16] Reaka-Kudla, M. L. Ecological diversity and conservation priorities in crustacea. Abstracts of the Crustacean Society 2000 Meeting, Puerto Vallarta, pp.41. 2000.

[17] Abell, R.A., Olson, D.M., Dinerstein, E., Hurley, P.T. Diggs, J.T., Eichbaum, W., Walters, S., Wettengel, W., Allnutt, T., Loucks, C. and Hedao, P. Freshwater ecoregions of North America. A conservation assessment. Island Press, Washington. 2000.

[18] Gilpin, M. E. and Soulé, J. Minimum viable populations: Processes of species extinctions. Conservation biology: the science of scarcity and diversity, ed, Soulé, M. E. Sinauer Associates, pp.19-34. 1986. 
[19] Taylor, C. A. Preserving North America's unique crayfish fauna. In: Freshwater ecoregions of North America. A conservation assessment, eds. Abell, R.A., Olson, D.M., Dinerstein, E., Hurley, P.T. Diggs, J.T., Eichbaum, W., Walters, S., Wettengel, W., Allnutt, T., Loucks, C. and Hedao, P. Island Press, Washington, pp.36-37. 2000.

[20] Martínez, M. and García, A. Flora y Vegetación acuática de localidades selectas de Querétaro. Acta Botánica Mexicana, 54, pp.1-23. 2001.

[21] Philip, R. 2001. Ecosystems and human health. CRC Press. USA.

[22] Axelrod, R., van Deveer, S. and Downie, L. The global environment. CQ Press. 2011.

[23] Gutiérrez-Yurrita, P. J. Los corredores ecológicos como herramienta para paliar los efectos negativos del cambio climático sobre la biodiversidad. Derecho Ambiental y Ecología, 4(21), pp.55-63. 2007.

[24] United Nations Conference on the Human Environment. Stockholm, 1972.

[25] Gutiérrez-Yurrita, P. J. and López-Flores, M.A. Reflexiones iusambientalistas sobre los criterios para proponer espacios naturales protegidos: hacia una nueva categoría de conservación, el Paisaje metafisico [o espiritual]. Revista Aranzadi de Derecho Ambiental, 20(2), pp.40-60. 2011. 